\title{
Estimating Remittances in the Former Soviet Union: Methodological \\ Complexities and Potential Solutions
}

Authors:

Jakhongir Kakhkharov,

PhD student, Griffith Business School, Department of Accounting, Finance, and Economics, Gold Coast campus, Griffith University, Parklands Drive, Southport, Qld, 4222, Australia

Telephone: +61(0) 755529268

Fax: +61(0) 755528068

Email: jakhongir.kakhkharov@griffithuni.edu.au

Dr. Alexandr Akimov,

Senior Lecturer, Griffith Business School, Department of Accounting, Finance, and Economics, Gold Coast campus, Griffith University, Parklands Drive, Southport, Qld, 4222, Australia

Telephone: +61(0) 755528579

Fax: +61(0) 755528068

Email: a.akimov@griffith.edu.au

\begin{abstract}
Migrant remittances have been an important part of economic development for many years; however, they became an important element of neo-transitional economies only recently. In post-Soviet countries, migrant remittances grew rapidly over the past decade and reached staggering levels. Remittances in some countries have become a major driver of economic development, and are larger in scope than foreign direct investment (FDI) and foreign assistance. For example, in Armenia, Kyrgyzstan, Moldova, Tajikistan, and Uzbekistan remittances now account for over $10 \%$ of GDP. Research in the area is largely sparse primarily due to lack of accessible data and recent nature of the phenomenon. The study is set to contribute in closing this gap.
\end{abstract}

The aim of this paper is to provide a comprehensive review of existing remittance measurement methodologies. We propose practical methods to adjust the Central Bank of Russia data to derive more accurate remittance estimates in selected countries of the former Soviet Union. These selected economies are major recipients of remittances among transition economies and account for as much as $10 \%$ of remittances worldwide. There have been attempts to provide this type of estimation in individual countries however there have been no studies to our knowledge that propose a general methodology for the whole region. 


\section{Introduction}

Migrant remittances in the former Soviet Union are a relatively recent trend. However, they became an important element of neo-transitional economies from the beginning of the 2000s. The growth rate of remittances over the past decade is remarkable. In some countries of the former Soviet Union, remittances have reached staggering levels. For example, in Armenia, Kyrgyzstan, Moldova, Tajikistan, and Uzbekistan remittances now account for over $10 \%$ of GDP, with Tajikistan leading the pack with annual remittances of approximately $40 \%$ of GDP. Remittances in this group of economies now exceed foreign direct investment (FDI) and foreign assistance. Because this rapid rise in remittances is a relatively recent trend and obtaining reliable data is difficult, this area of research has been underexplored.

Data availability improved in 2006 when the Central Bank of Russia (CBR) began publishing data on money transfers from Russia through money transfer operators (MTOs) by recipient country. Moreover, the CBR publishes the cross-border transactions of individuals (both residents and non-residents) conducted through all credit institutions (including MTOs). The statistics demonstrate that the largest proportion of remittances is channeled through MTOs. In 2012, the total volume of cross-border flows to the CIS (Commonwealth of Independent States) countries via all credit institutions equaled $\$ 19.2$ billion, whereas money transfers through MTOs amounted to $\$ 18.2$ billion. Approximately $80 \%$ of this $\$ 1$ billion difference is due to transfers to Ukraine, Armenia, and Georgia - countries with more developed financial systems ${ }^{1}$. Remittances to these countries are often sent using bank wire transfers. The fact that the majority of remittances are conducted via MTOs is unfortunate because remittances sent through the banking sector are more likely to be retained within the 
banking sector in the form of deposits and therefore possess greater potential for economic development.

The datasets published by the Central Bank of Russia allow estimation of the volume of remittances from Russia to the former Soviet republics. Because Russia is the major source of remittances for these economies, the estimation and analysis of these flows is very important for economic policy making in neo-transitional economies. The aim of this paper is to undertake a comprehensive review of existing knowledge on the scope, scale and estimation methodologies applicable to ex-Soviet republics, as well as contemporary challenges. Moreover, we suggest a potential method to improve the accuracy of remittances estimation, by adjusting data published by the Central Bank of Russia. Global financial crisis had a significant term impact on remittances from Russia. However, despite its continuous drag on the global financial markets, decline in remittances from Russia was very brief. In 2009, remittances from Russia bounced back and currently greatly exceed pre-crisis levels. Some post-Soviet economies are major recipients of remittances and as a group account for as much as $10 \%$ of remittances worldwide. There have been attempts to provide this type of estimation in individual countries however there have been no studies, to our knowledge, that provide a comprehensive analysis of remittances and their estimation problems that propose ways to improve estimation accuracy for the region. Remittances in this region frequently flow through unofficial channels. Moreover, a large share of petty trade is disguised as remittances which makes the accurate estimation of remittances difficult (Ibragimova et al., 2008; Mughal, 2007; Rustamov, 2008). Therefore, we propose adjusting the official statistics to account for informal remittances and petty trade. 
This paper consists of seven sections. Section 2 briefly introduces the institutional setting in which the flow of remittances to the post-Soviet region takes place. This section also describes the trends, magnitude and importance of these flows for the economies of the former Soviet Union. Section 3 reviews the concept of remittances as defined in the $5^{\text {th }}$ and $6^{\text {th }}$ editions of the IMF Balance of Payments Manuals. Although the most recent $6^{\text {th }}$ edition significantly revised the concept of remittances, its definition is still hampered by practical and methodological problems. Section 4 describes the problems involved in the estimation of remittances in the former Soviet Union. Section 5 analyzes and briefly evaluates some alternative methods to estimate remittances utilized by practitioners and researchers. In section 6, we propose adjustments to more accurately estimate remittances from Russia to selected former Soviet countries. Finally, section 7 summarizes the major findings of the paper. This section also provides suggestions to improve the remittance measurement framework.

\section{The Institutional Setting for Remittances in the Post-Soviet Region}

In 2012, the Russian Federal Migration Service (FMS) estimated the number of labor migrants entering the country to be approximately 11-14 million people per year. According to the FMS, $77 \%$ of these migrants come from the CIS (RIA-Novosti, 2012). Following this migration flow in the 2000 s, the scale of remittances in the post-Soviet region has also increased dramatically. Russia is the largest migrant receiving country and the main source of remittances into the other members of the CIS. According to the Central Bank of Russia, the total amount of money transfers sent from Russia to other CIS states increased by a factor of 36 between 1999 and 2012, that is, from $\$ 0.5$ billion to \$19.205 billion (CBR, 2012). 
The main recipients of remittances in the post-Soviet region are Uzbekistan, Tajikistan, Ukraine, Kyrgyzstan, Moldova, Armenia, Georgia, and Azerbaijan. Although there are no precise estimates, it is a stylized fact that remittances from Russia constitute the majority of remittances in these economies. Financial transfer channels between the major remittance recipient countries in the former Soviet Union and Russia can be divided into two categories: "formal" or "official" and "informal" or "unofficial" remittance channels. The official channels utilize banks and money transfer operators. Unofficial channels utilize friends, relatives, methods similar to "hawala"2, exchange through electronic accounts and transporting money themselves.

Armenia provides a good example of the disarray in the estimation of remittances. Tumasyan et al. (2008), based on a survey of 3000 respondents in Armenia, estimated total remittances to Armenia at $\$ 381$ million in 2006 . However, IMF Balance of Payments statistics estimated total remittances at $\$ 505$ million in the same year. The Central Bank of Russia reported that Russia alone transferred $\$ 604$ million in remittances via MTOs and postal offices to Armenia in $2006^{3}$ (Shelburne and Palacin, 2007). The survey conducted by Tumasyan et al. (2008) indicated that $58 \%$ of all remittances were received through banks and MTOs. That same survey reported that $76.9 \%$ of all remittances originated in Russia. However, another survey conducted by Central Bank of Armenia in 2005 suggests that $78 \%$ of all remittances were received via banks and MTOs (Central Bank of Armenia, 2006).

Different estimates of remittances to Azerbaijan are also difficult to reconcile. A survey conducted with funding from the Asian Development Bank (ADB) estimated total remittances to Azerbaijan at $\$ 428$ million in 2006 , whereas the balance of payments data for Azerbaijan suggests workers' remittances and migrant transfers through MTOs and banks of $\$ 679$ million (Rustamov, 2008). The same survey found 
that transfers through MTOs and banks accounted for $32 \%$ of remittances to Azerbaijan in 2006, which increases the total amount of remittances to Azerbaijan to $\$ 2.1$ billion. Data from the Russian Central Bank suggest remittances from Russia through MTOs and postal offices alone of $\$ 440$ million (Shelburne and Palacin, 2007). Russia was the source of $83 \%$ of all remittances to Azerbaijan in 2006 (Rustamov, 2008).

Despite the aggravation of political relations between Georgia and Russia in 2006, Russia continues to generate a significant flow of remittances to Georgia. The Russian Federation accounted for $56 \%$ of remittances to Georgia in 2010 (Melkadze, 2012). This same study noted data from the National Bank of Georgia estimating that the total amount of remittances sent through official channels to Georgia in 2011 reached $\$ 940$ million, which represents approximately $8.1 \%$ of the GDP of Georgia. The Central Bank of Russia estimated remittances to Georgia via MTOs and banks of \$754 million (CBR, 2011).

An ADB funded study by lbragimova et al. (2008) estimated remittances in 2006 to Kyrgyzstan at \$253 million, whereas the Kyrgyz National Bank estimate for the same year indicates that remittances exceeded $\$ 730$ million. The Russian Central Bank reported remittances to Kyrgyzstan from Russia for the same year of \$438 million (Shelburne and Palacin, 2007). Russia accounted for $82 \%$ of remittances to Kyrgyzstan in 2006 (Ibragimova et al., 2008). This report also found that nearly $78 \%$ of all remittances to Kyrgyzstan were transferred through banks and MTOs in 2006. Mogilevsky and Atamanov (2008) noted that large $(\$ 10,000-50,000)$ and very large (more than $\$ 50,000$ ) transactions made up $22 \%$ and $72 \%$ of all remittances, respectively, and concluded that the majority of funds in these types of transactions are actually the revenues of shuttle traders and repayments of loans for trade deals. 
Luecke et al. (2009) estimated that the total value of remittances to Moldova was approximately $\$ 1.5$ billion and $\$ 1.9$ billion in 2007 and 2008, respectively. The Russian Central Bank report on cross-border transfers via MTOs and postal offices estimated remittances from Russia to Moldova of $\$ 832$ million and $\$ 1.143$ billion in 2007 and 2008, respectively (CBR 2007, 2008a).

Brown et al. (2008), utilizing data from the National Bank of Tajikistan (NBT), estimated that the value of remittances through official channels to Tajikistan was $\$ 1.13$ billion in 2006 . The data from the Russian Central Bank suggest that the value of remittances from Russia through MTOs and postal offices was equal to $\$ 957$ million in the same year (Shelburne and Palacin, 2007). Brown et al. (2008) estimated that Russia was the source of $83 \%$ of total remittances to Tajikistan in 2006 , and approximately $10-15 \%$ of remittances via official channels were related to shuttle trade. Citing NBT representatives, Brown et al. (2008) note that $10-15 \%$ of remittances were transferred to Tajikistan informally in 2006. Mughal (2007) estimates a slightly higher share, $18.5 \%$, of informal transfers based on Khatlon Living Standards Survey and notes that this share should be further adjusted for in-kind transfers valued at approximately $7 \%$ of total transfers.

The following balance of payments data from the National Bank of Ukraine, presented in Table 1, were prepared according to the $6^{\text {th }}$ edition of the IMF Balance of Payments and International Investment Manual of IMF:

Table 1. Remittances to Ukraine in millions of \$

\begin{tabular}{lccccc}
\hline Description & $\mathbf{2 0 0 8}$ & $\mathbf{2 0 0 9}$ & $\mathbf{2 0 1 0}$ & $\mathbf{2 0 1 1}$ & $\mathbf{2 0 1 2}$ \\
\hline Total remittances & 6177 & 5370 & 5862 & 7019 & 7526 \\
Through informal channels & 805 & 713 & 777 & 963 & 1035 \\
From the Russian Federation & NA & NA & 1619 & 1988 & 2350 \\
Remittances as a \% of GDP & 3.4 & 4.6 & 4.3 & 4.3 & 4.3 \\
\hline
\end{tabular}

Source: National Bank of Ukraine [NBU] (2013). 
Kupets (2012) reports estimates of remittances to Ukraine ranging from \$1.7 billion to 54 billion and highlights alternative estimates of the proportion of transfers occurring through informal channels, which range from 15 to $200 \%$ of official remittances. Table 2 presents the data from the Russian Central Bank for remittances to Ukraine originating in Russia.

Table 2. Remittances from Russia to Ukraine in millions of \$

\begin{tabular}{llll}
\hline Description & $\mathbf{2 0 1 0}$ & $\mathbf{2 0 1 1}$ & $\mathbf{2 0 1 2}$ \\
\hline Remittances from Russia to Ukraine & 2201 & 2758 & 3162 \\
\hline Source: CBR $(2010,2011,2012)$ & & &
\end{tabular}

The State Committee for the Republic of Uzbekistan on Demonopolization (2006) draws from the Ministry of Labor to note that approximately $75 \%$ of the total workforce migrating from Uzbekistan traveled to the Russian Federation (State Committee for the Republic of Uzbekistan on Demonopolization, 2006). Uzbekistan has been the top recipient of remittances from Russia through MTOs since the Central Bank of Russia began publishing these data in 2006 .

\section{Review of Remittances Measurement Methodologies}

To understand the challenges encountered in measuring remittances, it is useful to define the major concepts. The sixth edition of the IMF Balance of Payments and International Investment Position Manual (International Monetary Fund, 2009, p. 272) notes that "remittances represent household income from foreign economies arising mainly from the temporary or permanent movement of people to those economies." Remittances include cash and noncash items that flow through formal channels, such as wire transfers, or through informal channels, such as money or goods carried across borders. Remittances consist primarily of funds and noncash items from individuals who have migrated to a new country and became residents there; these 
funds also include the net compensation of border, seasonal, or other short-term workers who are employed in an economy in which they are not resident. According to the IMF (International Monetary Fund, 2009, p. 272), "The two items in the balance of payments framework that substantially relate to remittances are "compensation of employees" and "personal transfers." Both of these standard components are recorded in the current account".

Total remittances encompass personal remittances, which consist of the compensation of employees, personal transfers, and capital transfers between households and social benefits. Social benefits include "benefits payable under social security funds and pension funds. They may be in cash or in kind" (International Monetary Fund, 2009, p. 213). Thus, the total amount of remittances includes income from individuals working abroad for short periods, from individuals residing abroad and sending transfers, and from social benefits from abroad.

The most notable change in the new edition of BPM6 that is relevant to remittances is in "personal transfers," which replaces the concept "workers' remittances" in the BPM5. In addition, the new manual includes transferrable social benefits in the definition of remittances.

Many authors have previously criticized the definition of "workers' remittances" for its link to the UN's concept of a long-term migrant, which consists of residents staying for 12 months or more (Alfieri et al., 2006). This concept excluded seasonal migrants and second - generation migrants. The exclusion of seasonal migrants and their remittances in the former Soviet Union was especially misleading because labor migration in this region is predominantly seasonal. Furthermore, the previous definition of remittances included only officially recorded migrants and their families. However, 
it is estimated that majority of labor migrants from former Soviet Union countries working in Russia are not frequently given formal labor agreements by their employers. In some cases, remittances might be channeled through employers and acquaintances in Russia. Therefore, these payments are not captured in the BoP statistics on remittances.

The distinctive feature of the IMF's new definition is the absence of the concept of "migrant". Rather, new definitions are based on the concept of "residence", a broader concept that incorporates a larger migration process. The manual stipulates that personal remittances include transfers originating from individuals who are not migrant workers. In other words, transfers from second-generation and naturalized citizens are included in the new version of the manual. Another improvement is that the definition of personal transfers, consistent with the 1993 System of National Accounts' definition, encompasses all transfers from residents to non-residents whatever the source of income, the relationship between them, and the purpose of the transfer. In addition, the BPM6 also extends the concept of total remittances and transfers to non-profit institutions serving households (NPISHs). This item is the sum of personal remittances, social benefits (defined as "disposable income from abroad"), and current transfers to NPISHs. The BPM6 significantly broadens and improves the conceptualization of remittances in previous definitions. However, the revision further complicates the measurement of remittances. For instance, practical problems in identifying particular population groups, such as second - generation migrants, utilizing survey data often prevent their inclusion in measurement (Lerch et al., 2008). Therefore, many countries either do not report remittances in BoP or provide extremely inaccurate estimates. 
As noted above, some migrant workers (in the case of labor migration in the CIS, most likely the majority of workers) reside in a recipient country temporarily and seasonally. Upon returning home, many migrants bring personal assets that will be owned by the household of origin. However, this type of asset is nearly impossible to account for in balance of payments transactions; therefore, these are not recorded as transfers. These in-kind transfers resemble imports of foreign goods. Unlike cash transfers that can be invested or utilized to purchase locally produced goods, these imports have, at best, no effect on GDP. In some cases, they may even have a negative substitution effect.

Furthermore, the new definitions include the compensation of employees in the measure of remittances and do not suggest a methodology for separating the part of compensation of short-term workers sent or returned to the country of origin. Obviously, not all of the income that individuals earn while working abroad will be transferred to the country of origin, and some of this money will be spent in the recipient country. For instance, Shelburne and Palacin (2007), referring to a 2005 World Bank survey, note that workers from Tajikistan spent approximately half of the income they earned in Russia for living expenses in Russia.

The propensity to spend in a host country might differ for migrants from various countries. Migrants from countries with levels of higher per capita income might be inclined to spend more in a host country compared to those from a country with a lower level of per capita income.

The underreporting of received remittances in surveys is observed in many countries (Shonkwiler et al., 2011). Possible reasons for this underreporting include: (i) the perceived risk of taxation of remittance income by the less educated population 
and (ii) the fear that a substantial amount of remittances may affect eligibility to receive payments or benefits from state and foreign aid organizations. Shonkwiler et al. (2011) note another potential reason - understating wealth/income to limit the demands of poorer relatives and neighbors for informal loans and advances to support their livelihood.

Thus, despite major improvements to the definition of remittances in the IMF (2009) Manual on the Balance of Payments (BOP), additional room for improvement exists. More precise measurement of remittances requires some adjustments. This precision is important to the proper evaluation of the impact of remittances on various types of economic activities in countries receiving these remittances. Current remittance measurement tools, econometric models, and worldwide surveys suffer from serious problems. These methods are unlikely to measure remittances with a high degree of accuracy not only because migration and remittances are an infrequent, although growing phenomena, but also because of various complex issues entailed in migration and remittances (Lerch et al., 2008).

In cases where the data is sufficient to produce reliable estimates of the size of official transfers (e.g., Russia-CIS remittances where the outflow of workers' remittances is calculated utilizing data provided by MTOs and special banks), it is possible to estimate the total amount of remittances if the ratio of informal to formal remittances is known. This calculation is based on the assumption that labor migrants and their families have little incentive to lie about which channel they utilize to remit funds (Mughal, 2007). However, even in such cases, not all of the transfers are related to migrants' transfers because some of them could be related to trade. In other words, part of the transfers via MTOs must be classified as the export receipts of shuttle traders. This ratio may vary significantly for transfers from different migrant receiving 
countries. The proportion of remittances transferred through MTOs for neighboring countries such as Kazakhstan-Uzbekistan or Russia-Belarus might seem insignificant because migrants prefer to carry cash themselves when returning to their country of origin. The ratio of informal to formal remittances is unlikely to remain constant over time and is very sensitive to transfer commission fees charged by MTOs, MTO branch network both in host and home countries, migrants literacy in using financial services, as well as legal complexity/documentation requirements for sending and receiving funds using MTOs.

In general, our definition of remittances encompasses both transfers through financial system as well as cash returned to the home country. In-kind transfers appear to be associated with a small - scale trade, and a sizeable share of small scale trade is disguised as remittances in the CIS, which we exclude from estimates of total remittances. In the next section, we will discuss the relationship between formal and informal transfers in the former Soviet Union in greater detail.

\section{Remittances and Remittance Transfer Channels in the Former Soviet Union.}

Until very recently, it was customary to transfer money through a network of relatives and acquaintances, train and airplane crews, bus drivers, and delivery services. However, evidence from the Khatlon Living Standards Survey (KLSS) in Tajikistan analyzed by Mughal (2007), as well as research conducted by Ibragimova et al. (2008); Luecke et al. (2009); Poghossian et al. (2010); Tumasyan et al. (2008) and a small-scale survey in Uzbekistan conducted by the authors reveals that the utilization of informal channels is gradually decreasing.

According to the Central Bank of Russia (2012), Uzbekistan and Tajikistan are the two largest recipients of remittances from Russia. It is believed that the greater 
volume of remittances from Russia is transferred through MTOs today than a few years ago. For example, a survey conducted by one of the authors in 2009 as part of a consulting project with the assistance of the Tashkent Regional Bureau of Employment of Citizens Abroad revealed that $74.8 \%$ of funds transferred home by respondents are transmitted through formal channels and only $25.2 \%$ of funds are transmitted through informal channels. The data from this survey was collected via contact interviews based on a standard questionnaire. A standard questionnaire was used because it is a more effective method to cover a large scope of migrants and it was less time consuming. The questionnaires were distributed to the migrants in the Tashkent area (mainly at the airport and train stations) through the Tashkent Regional Bureau of Employment of Citizens Abroad. Some interviews were conducted by phone or face-to-face. In total 85 people were interviewed in Tashkent. Sixty eight per cent (59 people) of the sample group were urban residents and 32 per cent (26 people) were from a rural population. Sixty four per cent of respondents were male and 36 per cent female. In terms of regional distribution, the respondents represented a good mix from all 12 regions of Uzbekistan and Karakalpakstan Autonomous Republic, although 51 per cent of people interviewed were from the Tashkent or Tashkent region. The average age of respondents was 34 years and 29 per cent of respondents possessed university degree qualifications.

Post-Soviet Republics, with the exception of Georgia, do not tax remittances, which combined with the favorable regulation of MTOs, encouraged the development of the remittances market. MTOs offer near to instant transactions (de Luna-Martinez 2005). They promise the receipt of funds in another country within a few minutes to a few hours. 
Migrant workers from the former Soviet Republics rarely utilize bank accounts because opening a bank account is often costly and time consuming. Moreover, many migrant workers may face legal obstacles to opening an account in the host country due to their undocumented status there. Therefore, account-to-account transfers are less convenient than instant cash money transfers.

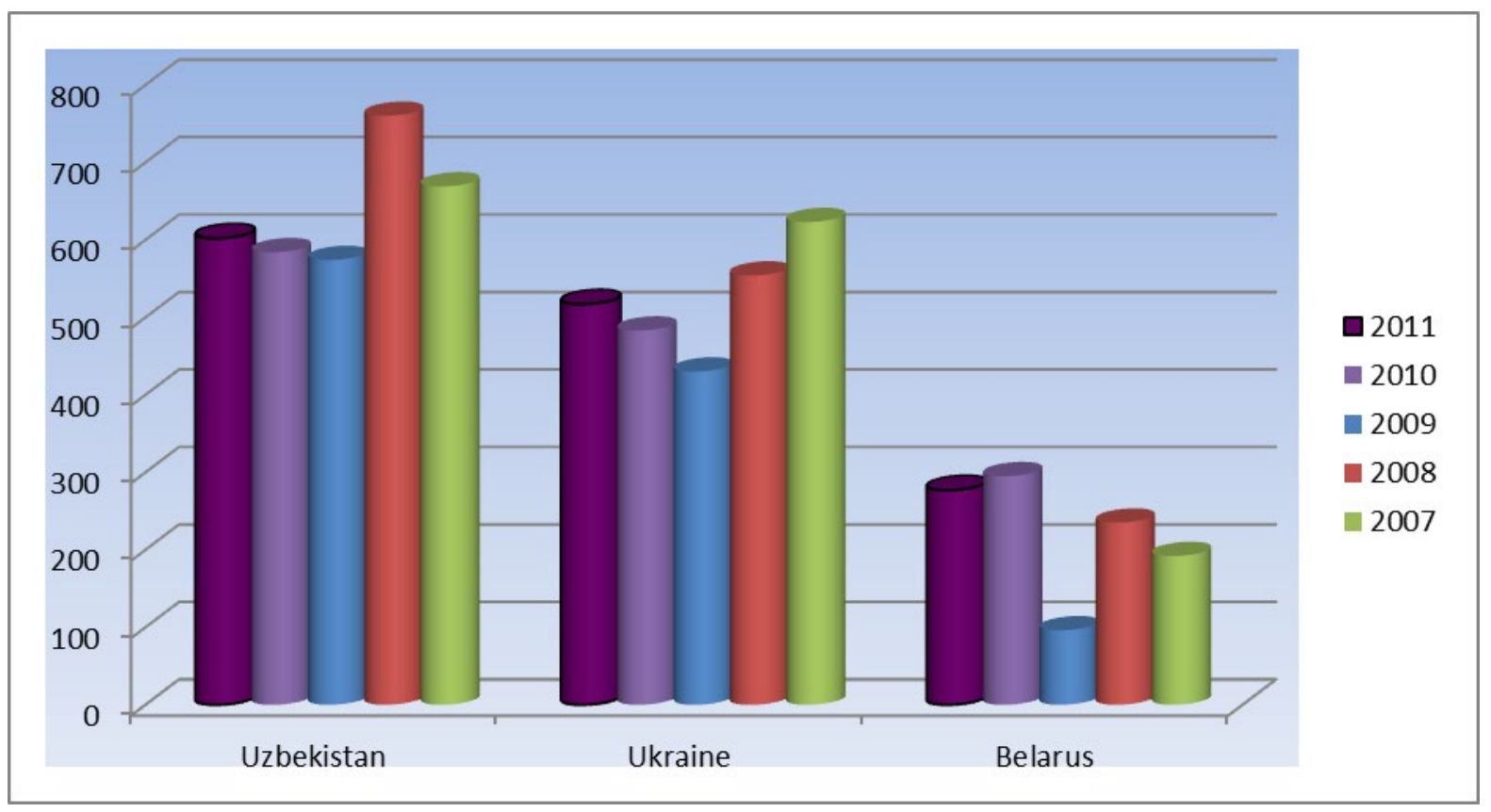

Figure 1. Average Remittance value for Uzbekistan, Belarus, and Ukraine

Figure 1 provides a comparison of transfer patterns within the CIS. This figure indicates that the average amount transferred to Uzbekistan is significantly higher than the average amount transferred to Ukraine and Belarus. Ukraine and Belarus were selected for this comparison because these countries have migrants who are typically more skilled than those from Uzbekistan and consequently earn higher wages than Uzbek migrants.

Several explanations exist for this phenomenon. Transfers to Uzbekistan are frequently consolidated, that is, several persons combine their savings and transfer the funds to a person who distributes this amount among several beneficiaries 
(Gusman, 2007; Zykova, 2008). Gusman (2007) observes that migrant utilize two primary channels to remit funds: documented migrants transfer money themselves, whereas undocumented migrants utilize the assistance of an intermediary. This logic implies that the level of undocumented migration can be estimated by comparing the number of senders and the number of recipients. At the beginning of 2009 , the number of recipients per sender decreased, which indicates a decrease in the level of undocumented migration (RusSlavBank, 2009). In other words, the GFC-related crisis in Russia and job losses mainly affected undocumented migrants and a significant number of these workers returned home. Most documented migrants were unaffected and continued to work in Russia. This difference could also result from the process described by the gravity model of workers' remittances developed by Lueth and RuizArranz (2006). These authors find that reported remittances through MTOs to a country that shares a border are approximately $50 \%$ of the level of remittances for the equivalent country that does not share a border. In other words, reported remittances are usually lower because a higher percentage of transfers are conducted through informal channels ${ }^{4}$. The higher level of remittances from Russia to Uzbekistan compared to Ukraine and Belarus could reflect differences in the levels of per capita income in these countries. The higher the per capita income in a country, the lower the amount transferred home (Lueth and Ruiz-Arranz, 2006).

Towards the end of the 1990s and the beginning of the 2000s, the majority of transfers from Russia were made through informal channels. Tyuryukanova (2005) found in a study sponsored by the International Labor Organization that $75 \%$ of surveyed migrants transmitted money through informal channels and only $10 \%$ utilized services provided by MTOs and banks. A survey conducted in Moldova in 2004 reported that $30 \%$ of labor migrants utilized official channels and $70 \%$ utilized unofficial 
channels. This survey also indicated that $70 \%$ of migrants from Moldova were undocumented (Black et al., 2007).

Recent reductions in rates by MTOs could be a competitive response to the global economic slowdown in 2009. For example, the average fee for remittances was slightly over 10\% in 2002 when only three MTOs were operating in Uzbekistan. By 2005, ten companies were operating and the average fee dropped to 4-5\% (State Committee for the Republic of Uzbekistan on Demonopolization, 2006). By 2009, the average transfer fees had decreased to $2-3 \%$. The total value of transfers from Russia to Uzbekistan in 2009 was approximately $\$ 3$ billion, and Uzbek migrants saved approximately $\$ 90$ million in fees in 2009 compared to 2005 . These savings provided a good incentive to switch from informal to formal channels of transferring funds. However, $15 \%$ of respondents continued to cite high transfer fees as the single most important reason for not utilizing MTO services in 2009. Figure 2 depicts the downward trend in fees for different sizes of transfers.

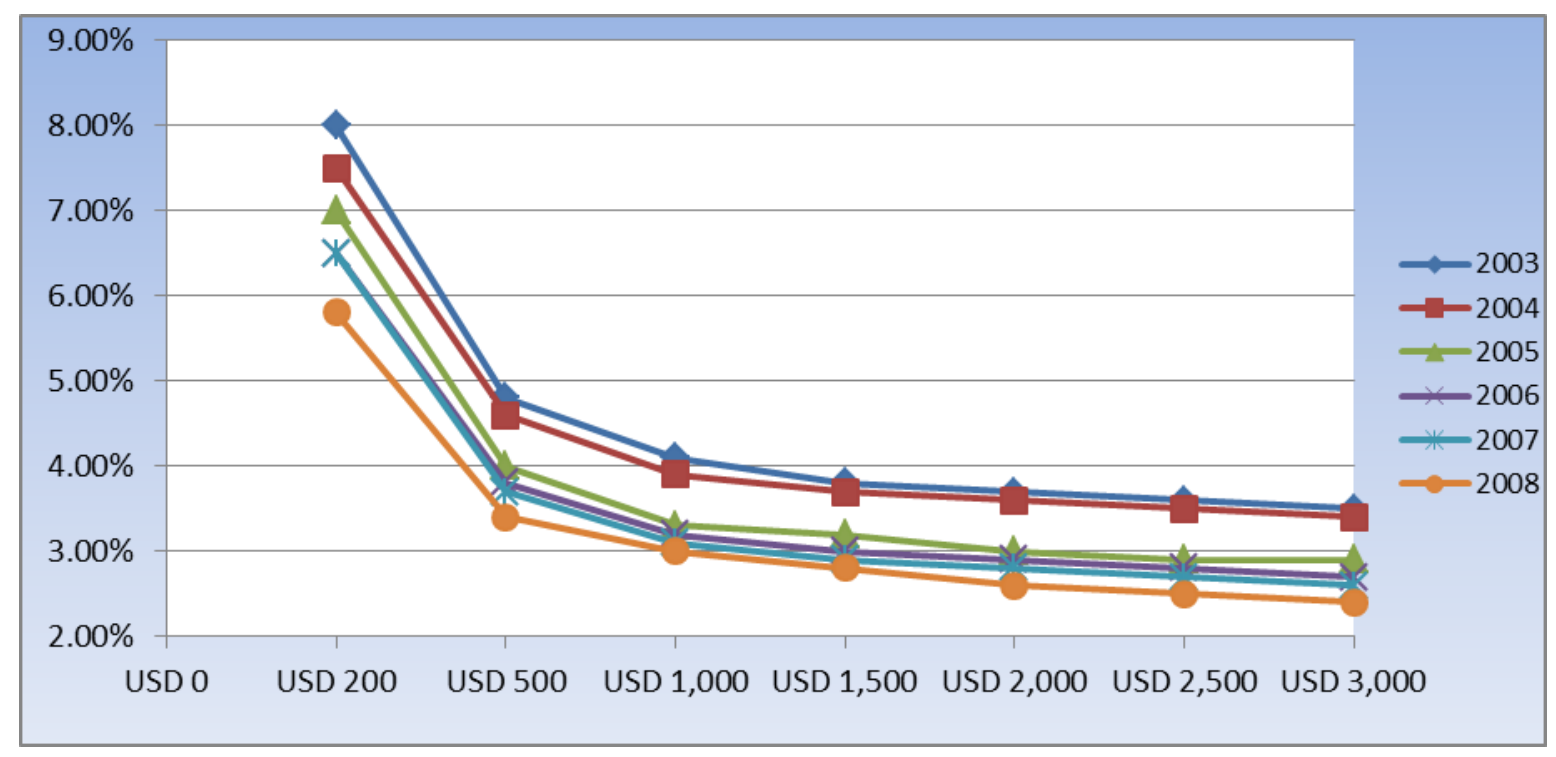

Figure 2. Average fee (for remittances from Russia via MTOs). Source: CBR (2008b) 
Thus surveys and research in various countries of the former Soviet Union, despite differing from each other in terms of their focus, suggest that informal remittances as a percentage of formal remittances are decreasing over the years. Below is the table which sums up these surveys and their results.

Table 3. Survey data on use of formal vs informal channels for remitting money in the CIS

\begin{tabular}{|c|c|c|c|c|c|c|}
\hline & $\begin{array}{l}\text { \% formal } \\
\text { remittances } \\
\text { in total } \\
\text { remittances }\end{array}$ & Country & Source & $\begin{array}{c}\text { Share of } \\
\text { households } \\
\text { receiving } \\
\text { via } \\
\text { MTO/Bank }\end{array}$ & Migrant & $\begin{array}{l}\text { Third } \\
\text { party }\end{array}$ \\
\hline 2003 & $56 \%$ & Moldova & $\begin{array}{l}\text { Ghencea and } \\
\text { Gudumac } \\
\text { (2004) }\end{array}$ & $\begin{array}{l}48 \% \\
(72.2 \% \\
\text { informally) }\end{array}$ & & \\
\hline 2004 & & Tajikistan & $\begin{array}{l}\text { Migration, } \\
\text { Remittances } \\
\text { and Living } \\
\text { Standards in } \\
\text { Tajikistan } \\
\text { (Mughal, 2007) }\end{array}$ & $\begin{array}{l}59 \% \text { (41\% } \\
\text { informally) }\end{array}$ & & \\
\hline 2005 & & Tajikistan & $\begin{array}{l}\text { Migration, } \\
\text { Remittances } \\
\text { and Living } \\
\text { Standards in } \\
\text { Tajikistan } \\
\text { (Mughal, 2007) }\end{array}$ & $\begin{array}{l}64 \% \text { (36\% } \\
\text { informally) }\end{array}$ & & \\
\hline 2006 & $58 \%$ & Armenia & $\begin{array}{l}\text { ADB } \\
\text { (Tumasyan, } \\
\text { 2008) }\end{array}$ & $\begin{array}{l}69 \%(31 \% \\
\text { informally) }\end{array}$ & $27.9 \%$ & $12 \%$ \\
\hline 2006 & $29.91 \%$ & Azerbaijan & $\begin{array}{l}\text { ADB } \\
\text { (Rustamov, } \\
2006 \text { ) }\end{array}$ & $\begin{array}{l}32.12 \% \\
(68 \% \\
\text { informally) }\end{array}$ & $47.23 \%$ & $22.92 \%$ \\
\hline 2006 & $77.8 \%$ & Kyrgyzstan & $\begin{array}{l}\text { ADB } \\
\text { (lbragimova et } \\
\text { al., 2008) }\end{array}$ & & $3.3 \%$ & $18.6 \%$ \\
\hline 2006 & $58.7 \%$ & Tajikistan & $\begin{array}{l}\text { ADB (Brown, } \\
\text { Olimova, } \\
\text { Boboev, 2008) }\end{array}$ & $\begin{array}{l}80.3 \% \\
\text { (74\% } \\
\text { informally) }\end{array}$ & $34.6 \%$ & $6.7 \%$ \\
\hline 2006 & & Moldova & $\begin{array}{l}\text { IOM-CBSAXA } \\
\text { (Lucke et al, } \\
\text { 2009) }\end{array}$ & $\begin{array}{l}49 \%(51 \% \\
\text { informally) }\end{array}$ & & \\
\hline 2006 & & Georgia & $\begin{array}{l}\text { Georgia's } \\
\text { National Public } \\
\text { Opinion Survey }\end{array}$ & $\begin{array}{l}64 \% \text { (total } \\
\text { for world), } \\
76 \% \text { (from } \\
\text { Russia) }\end{array}$ & & \\
\hline 2007 & & Armenia & $\begin{array}{l}\text { CRRC } \\
\text { Migration and } \\
\text { Remittances, } \\
\text { Data from } \\
\text { CRRC DI } \\
\text { Surveys } \\
(2007 \mathrm{c})\end{array}$ & $\begin{array}{l}85 \% \text { (33\% } \\
\text { informally) }\end{array}$ & & \\
\hline
\end{tabular}




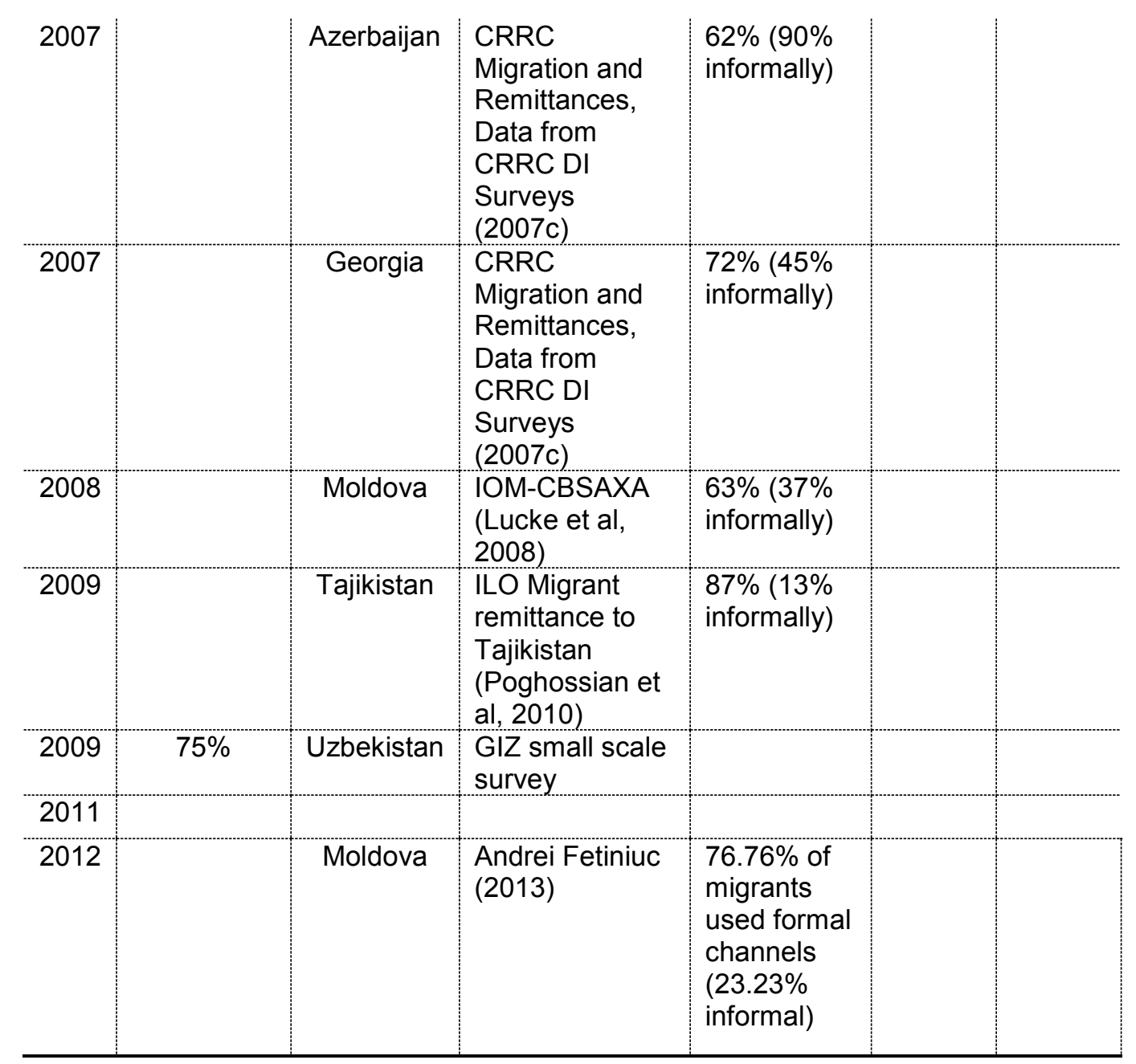

\section{Estimation Methods}

The goal of this section is to undertake the analysis of the remittances estimation challenges in post-Soviet countries and discuss applicability of existing remittances estimation methods that may help us to overcome some of those challenges. Ultimately, we aim to arrive with a method which will provide us more accurate data on remittances in the former Soviet republics.

Both the small-scale survey conducted by an author and other studies in this area indicate that most funds are currently transferred through MTOs. However, there is still a significant fraction of remittances made using informal channels, which is not captured by official statistics. Moreover, inaccuracies may arise by treating some 
transfers as remittances whereas they are, in fact, payments for small-scale shuttle trade. Therefore, a researcher attempting to study the effects of remittances on these economies should make appropriate adjustments to the data to improve its accuracy.

Accurate estimation of remittances in this region is further hampered by the fact that the majority of the former Soviet economies do not publish remittance data consistent with IMF methodological guidelines. On the contrary, some countries, such as Uzbekistan and Turkmenistan, either publish very limited statistics or do not publish remittances statistics at all. In other cases, data quality is questionable, and different methodologies hamper verification of the data on remittances from other sources (Shelburne and Palacin, 2007). This problem is not limited to this region; the quality of remittance data is poor globally (Kapur, 2004; Lerch et al., 2008; Shelburne and Palacin, 2007). In contrast, some of the former Soviet republics, such as Kazakhstan, Tajikistan, Moldova, and Russia, provide more statistics on remittance senders and recipients than most countries in the world. However, data problems exist and policy makers, central banks, and scholars examining remittances resort to particular measurement methods or surveys to produce estimations.

One estimation methodology, a gravity model, traditionally utilized to explain trade and FDI, can also be applied to explain variations in bilateral remittances as in Lueth and Ruiz-Arranz (2006). Elaborating on concepts developed by Zipf (1946) and utilizing data for 11 countries in Asia and Europe, Lueth and Ruiz-Arranz (2006) found that flows are larger between larger countries. Larger countries receive and send larger volumes of remittances in dollar terms. They also find that the greater the distance between two countries, the smaller the flow of remittances. In addition, the study found that other variables such as the partner countries' GDP, a common border, 
and a common language explain over 50 percent of the variation in remittance flows across time and countries. Thus, the study predicts that remittance flows increase as the source country gets richer and recipient country gets poorer. Specifically, the empirical results of the gravity model argue that doubling the per capita GDP of the recipient country is likely to reduce remittances by a factor of four. If this finding holds after controlling for other factors (such as GDP, distance, etc.), Uzbekistan would receive 16 times the remittances from Russia than are received by Kazakhstan from Russia because Uzbekistan's per capita income is one eighth that of Kazakhstan. In addition, as noted above, remittances transmitted through formal channels to a country that shares a border are one-half of what they would be otherwise. Note that this prediction in the gravity framework is confirmed for the Kazakh-Uzbek remittance corridor. Todoroki, Celik, and Kholmatov (2011), utilizing data from the National Bank of Kazakhstan, notes that total transfers via MTOs from Kazakhstan to Uzbekistan in 2009 and 2010 were $\$ 189$ million and $\$ 212$ million respectively. Todoroki (2011) estimates at least 330,000 migrants from Uzbekistan were working in Kazakhstan in 2010. Makhmutova et al. (2008) estimate that remittances to Uzbekistan from Kazakhstan amount to approximately $\$ 1,522$ per migrant per year, an amount equal to at least $\$ 500$ million a year in remittances to Uzbekistan. This estimate is consistent with the (Makhmutova et al. 2008) estimate for total remittances to Uzbekistan per year in 2003-2004. Therefore, remittances to Uzbekistan via MTOs constitute approximately $40 \%$ of total remittances. The small scale-survey conducted by one of the authors indicates that informal remittances from Russia (which does not share a border with Uzbekistan), constitute approximately $25 \%$ of total remittances to Uzbekistan from Russia. Thus, the estimates based on the gravity model are roughly 
consistent with the proportion of formal to total remittances ratio for remittances from Russia and Kazakhstan to Uzbekistan.

The World Bank methodology for estimating remittances is based on migration data (Ratha and Shaw, 2007). However, data on migration within the former Soviet Union are of poor quality for both estimating yearly flows and the stocks from each country. Moreover, data on the stock of migrants in the former Soviet Union include a large number of permanent migrants. These are people returning to their country of origin rather than labor migrants. Permanent migrants have little motivation to remit unless some family remains in the home country. The majority of migrants in the former Soviet Union enjoys visa-free travel and can reside and work without undergoing a proper registration process, which makes the estimation of their numbers very difficult. These might explain why the World Bank did not provide an estimate of remittances for some Central Asian countries until recently, when the Russian Central Bank began to publish datasets on remittances in the CIS and the rest of the world, including transfers via MTOs.

Mughal (2007) estimates remittance flows to Tajikistan in 2004 and 2005 utilizing the ratio of informal to formal transfers. Data on formal worker remittances were drawn from the National Bank of Tajikistan. The author made a $10 \%$ adjustment to these formal workers' remittances because these data include small - scale trade. The ratio of informal to formal transfers is identified from the Khatlon ${ }^{5}$ Living Standards Survey conducted in 2005. According to Mughal (2007), Russia was the destination for $99 \%$ of migrants from Tajikistan. However, Brown et al. (2008) find that $83 \%$ of incoming remittances from abroad were sent from Russia. The ratio of informal to formal transfers in Tajikistan had been declining since the Mughal (2007) research 
was conducted because of lower transfer costs, better access to MTO services and simpler transaction procedures.

Lerch et al. (2008) described other methodologies utilized to account for remittances by agencies in Switzerland and in the USA. For example, the Swiss National Bank (SNB) utilizes extrapolation to calculate the outflow of remittances from Switzerland. The number of documented foreign workers is multiplied by mean wage to calculate the earnings of migrants. Residents are divided into those who reside and work in Switzerland with short-term, one-year, and permanent permits. Then, the SNB, without providing a justification, assigns fixed percentages of the average wage that these three groups of migrants send home $-25 \%, 12 \%$ and $5 \%$. In addition, border workers are assumed to remit $100 \%$ of their earnings. Thus, this very simple model does consider differences in the transfer behavior of migrants from various countries. According to Lerch et al. (2008), the US Bureau of Economic Analysis utilizes a more sophisticated model based on data from the US Census and the annual American Community Survey. These two sources collect data on all foreign-born residents, including undocumented migrants. This model incorporates many other factors important to the remittance decision, such as duration of residence, presence of children, and macroeconomic data for the recipient countries.

\section{The Adjustment Methodology and Its Application to Remittances in the Former Soviet Republics}

The previous section of this paper reviewed several methodologies for estimating remittances. Some of these methodologies, e.g., the gravity model and the model of the US Bureau of Economic Analysis, yield quite reasonable estimates of remittances but fail to include shocks such as economic crises and differences in remittance 
transferring behavior of labor migrants from different countries; most importantly, these estimates lack precision. Other methodologies (the World Bank and Swiss National Bank methodologies) are not applicable to the former Soviet Union where migration data are unreliable and borders are porous. However, the importance of remittance flows for many countries of the former Soviet Union is increasing. Thus, to increase the effectiveness of policy-making decisions, there is a need for a more precise methodology to estimate remittances in the former Soviet Union.

This section provides sample applications of how adjustments to the Central Bank of Russia may produce more accurate estimates of remittances from Russia to the selected countries of the former Soviet Union. In particular, the adjustments are made for small-scale trade, informal transfers and the border effect discussed previously.

The example of remittances from Russia to Uzbekistan in 2012 is utilized for illustration. According the Central Bank of Russia, remittances to Uzbekistan from Russia through MTOs and banks reached $\$ 5.693$ billion in 2012 (CBR, 2012). Based on the authors' interviews with migrants and their families, policy makers, and representatives of international organizations, approximately $10 \%$ of this amount represents small-scale trade. To adjust for small-scale trade, we subtract $10 \%$ from the amount of total remittances reported by the Central Bank of Russia. After this adjustment, remittances to Uzbekistan drop to $\$ 5.1$ billion. The next step is to make adjustments for informal remittances and the border effect. Because Russia and Uzbekistan do not share a border, we do not make adjustments for the border effect; however, we adjust for informal remittances so that they constitute $13.91 \%$ of total remittances. This estimate of informal remittances is based on the small-scale survey conducted by the authors in Uzbekistan in 2009 and further decrease in the share of 
informal remittances after 2009. This decrease in the share of informal remittances is associated with decrease in remittance fees, rapidly expanding branch network, and improved literacy of migrants in relation to MTO procedures, which have been taking place simultaneously. Table 4 below summarizes the remittance fees applicable for average amount of transfer for respective years based on data from Central Bank of Russia and associated with it decrease in the share of informal remittances estimated by authors. We sourced the data for share of informal remittances from existing surveys (see, Table 3) and link the rate of annual decline in the share of informal remittances with the reduction in transfer fees.

Table 4. Estimated decrease in the share of informal remittances associated with decrease in remittance fees

\begin{tabular}{c|c|c}
\hline Year & $\begin{array}{c}\text { Remittance fees for average } \\
\text { amount of remittance (\%) }\end{array}$ & $\begin{array}{c}\text { Informal remittances as a } \\
\text { share of total remittances (\%) }\end{array}$ \\
\hline 2006 & $3.7 \%$ & $40 \%$ \\
\hline 2007 & $3.3 \%$ & $33.48 \%$ \\
\hline 2008 & $3.03 \%$ & $29.08 \%$ \\
\hline 2009 & $2.78 \%$ & $25 \%$ \\
\hline 2010 & $2.44 \%$ & $19.46 \%$ \\
\hline 2011 & $2.3 \%$ & $17.17 \%$ \\
\hline 2012 & $2.1 \%$ & $13.91 \%$ \\
\hline
\end{tabular}

Source: Data on remittance fees and average amount of remittance for each year is from Central Bank of Russia.

These adjustments produce an estimate of $\$ 5.952$ billion in remittances to Uzbekistan in 2012. Because remittance transfer fees have decreased over time and awareness of the decrease spread gradually, the adjustment factor for informal channels has fallen gradually from $40 \%$ for 2006 to $13.91 \%$ in 2012 . Table 5 below summarizes these calculations for Uzbekistan. 
Table 5. Remittances from Russia to Uzbekistan in millions of US\$

\begin{tabular}{|c|c|c|c|c|c|}
\hline Year & $\begin{array}{c}\text { Reported } \\
\text { Remittances }\end{array}$ & $\begin{array}{l}\text { Share of } \\
\text { small scale } \\
\text { trade in } \\
\text { reported } \\
\text { remittances }\end{array}$ & $\begin{array}{l}\text { Share of } \\
\text { informal } \\
\text { transfers in } \\
\text { total } \\
\text { remittances }\end{array}$ & $\begin{array}{l}\text { Adjustment } \\
\text { for border } \\
\text { effect }\end{array}$ & $\begin{array}{c}\text { Remittances } \\
\text { adjusted for small- } \\
\text { scale trade, informal } \\
\text { transfers and border } \\
\text { effect }\end{array}$ \\
\hline $2006^{*}$ & 1,080 & $-10 \%$ & $40 \%$ & - & 1620 \\
\hline 2007 & 1,693 & $-10 \%$ & $33.48 \%$ & - & 2291 \\
\hline 2008 & 3,007 & $-10 \%$ & $29.08 \%$ & - & 3816 \\
\hline 2009 & 2,071 & $-10 \%$ & $25 \%$ & - & 2485 \\
\hline 2010 & 2,858 & $-10 \%$ & $19.46 \%$ & - & 3194 \\
\hline 2011 & 4,276 & $-10 \%$ & $17.17 \%$ & - & 4646 \\
\hline 2012 & 5,693 & $-10 \%$ & $13.91 \%$ & - & 5952 \\
\hline
\end{tabular}

Sources: Data from 2007 to 2012 are from the Central Bank of Russia (CBR 2007, 2008a, 2009, 2010, 2011, 2012).

*Data for the last three quarters of 2006 are also from the Central Bank of Russia. However, the first quarter data for 2006 are not available and were estimated to add to the available three quarters data for 2006.

Consider the example of remittances from Russia to Azerbaijan. Based on a survey of 3900 households, Rustamov (2008) estimates that only $32 \%$ of total remittances were received via banks and MTOs in 2006 . Thus, approximately $68 \%$ of all remittances to Azerbaijan occurred through informal channels in 2006. The share of informal transfers in Azerbaijan is much higher than Uzbekistan. This difference is consistent with the gravity model, which predicts higher volumes of informal transfers for countries with common borders. In fact, consistent with the gravity model estimates of Lueth and Ruiz-Arranz (2006), remittances to a country that shares a border are one-half of what would be expected. Because transfer fees have fallen in the former Soviet Union in the same pattern, it is assumed that the share of informal transfers has also been changing in a fashion similar to the pattern observed in Uzbekistan. Table 6 below summarizes the calculations for Azerbaijan. Note that, according to our calculations, the share of reported remittances through banks and MTOs in 2006 was $40 \%$ of total remittances - a number that is very close to the estimate from the survey conducted by Rustamov (2008). 
Table 6. Remittances from Russia to Azerbaijan in millions of US\$

\begin{tabular}{|c|c|c|c|c|c|}
\hline Year & $\begin{array}{c}\text { Reported } \\
\text { Remittances }\end{array}$ & $\begin{array}{l}\text { Share of } \\
\text { small scale } \\
\text { trade in } \\
\text { reported } \\
\text { remittances }\end{array}$ & $\begin{array}{l}\text { Share of } \\
\text { informal } \\
\text { transfers in } \\
\text { total } \\
\text { remittances }\end{array}$ & $\begin{array}{l}\text { Adjustment } \\
\text { for border } \\
\text { effect }\end{array}$ & $\begin{array}{c}\text { Remittances } \\
\text { adjusted for small- } \\
\text { scale trade, informal } \\
\text { transfers and border } \\
\text { effect }\end{array}$ \\
\hline $2006^{*}$ & 645 & $-10 \%$ & $40 \%$ & $200 \%$ & 1935 \\
\hline 2007 & 814 & $-10 \%$ & $33.48 \%$ & $200 \%$ & 2203 \\
\hline 2008 & 1,061 & $-10 \%$ & $29.08 \%$ & $200 \%$ & 2693 \\
\hline 2009 & 748 & $-10 \%$ & $25 \%$ & $200 \%$ & 1795 \\
\hline 2010 & 881 & $-10 \%$ & $19.46 \%$ & $200 \%$ & 1969 \\
\hline 2011 & 1,159 & $-10 \%$ & $17.17 \%$ & $200 \%$ & 2519 \\
\hline 2012 & 1,230 & $-10 \%$ & $13.91 \%$ & $200 \%$ & 2572 \\
\hline
\end{tabular}

Sources: Data from 2007 to 2012 are from the Central Bank of Russia (CBR 2007, 2008a, 2009, 2010, 2011, 2012).

*Data for the last three quarters of 2006 are also from the Central Bank of Russia. However, the first quarter data for $\mathbf{2 0 0 6}$ are not available and were estimated to add to the available three quarters data for 2006.

We realize that our estimation methods are not perfect. For example, in case of Azerbaijan, despite having a common border with Russia, anecdotal evidence suggests that the majority of Azerbaijani labor migrants reside in Moscow or Saint Petersburg which is far away from the border of Russia with Azerbaijan. Therefore, it is probably more convenient for them to transfer funds to Azerbaijan than bringing cash home in their pockets. However, the fact that the results of our estimations coincide with the survey estimations of Rustamov (2008) suggests that our methodology is good enough to make meaningful estimations. All in all, it seems that in the case of remittances from the CIS, this methodology makes quite precise estimations.

Similar estimates were produced for other countries of the former USSR (except Baltic countries). They are available from the authors upon request.

We made substantial adjustments to the estimates of remittances produced by Shelburne and Palacin (2007) prior to 2007 and to the data published by the Central 
Bank of Russia. These new estimates substantially change the value of remittances in some cases and could be used to analyze the impact of remittances in the economies of major recipients. Because remittances from Russia are by far the most significant source of remittances within the CIS, these data approximate the total amount of remittances that these countries receive.

\section{Conclusion}

This study has provided a comprehensive review of existing remittance measurement methodologies relevant to the countries of the former Soviet Union. This study also discussed problems with the IMF BoP framework and inaccuracies and weaknesses in other data sources.

The empirical evidence suggests that the share of formal remittance channels is growing at the expense of informal channels in the CIS. Labor migrants understand that carrying cash is risky - the money could be stolen or corrupt customs and passport control officers could expropriate part or all of this money. If a migrant sends earnings with another person, there is a risk that the money courier may deceive the sender.

The utilization of formal and informal channels also varies according to the distance separating the sending and receiving countries. Interviews and surveys also suggest that other factors can determine the choice of formal over informal channels: the education level of the migrant, the nature of employment, the presence of a migrant community/network, the average salary level, etc. More educated and white - collar migrants tend to send more money via MTOs.

The sheer size and significance of remittances makes harnessing this economic phenomenon to benefit the economy reasonable. Policies to increase the share funds 
transferred through formal channels rather than informal channels would be a first step in this direction. However, the eventual success of this first step depends on the institutional capacity of the financial/banking sector to transform the development potential of remittances into benefits for the country.

The aim of this paper was to review the remittance estimation methodologies and challenges in post-Soviet region as well as to propose some adjustments that may improve accuracy of remittance estimations. We believe this goal has been achieved. Despite its deficiencies the methods have reasonable empirical confirmation from existing surveys. This new methodology has a potential to be utilized in other regions and countries experiencing similar data challenges.

\footnotetext{
${ }^{1}$ As measured by EBRD banking sector development indicators, Transition Report (London: EBRD, 2012)

2 Hawala is an alternative informal transfer method utilized parallel to official channels and implies the use of brokers (hawaladars), family and regional ties and connections.

${ }^{3}$ Data for remittances via MTOs is utilized for 2006 because data for total remittances in 2006 are not available by country for the entire year. Data are available for the last three quarters of 2006 only.

${ }^{4}$ Carrying cash upon returning home is considered to be an informal channel of remittance.

${ }^{5}$ One of five regions, and the poorest, in Tajikistan.
} 


\section{References}

Alfieri, A, Havinga, I \& Hvidsten, V 2006, "Issue Paper: Definition of remittances", Meeting/conference of the United Nations Technical Subgroup on Movement of Persons-Mode 4, New York.

Black, R, Pantiru, MC \& Sabates-Wheeler, R 2007, "Migration and poverty reduction in Moldova", Working Paper C 10, Sussex Centre for Migration Research and Institute for Development Studies, Falmer, 2007.

Brown, R, Olimova, S \& Boboev, M 2008, "Country report on remittances of international migrants in Tajikistan", Study on International Migrants' Remittances in Central Asia and South Caucasus, Asian Development Bank, Manila, 2008.

Central Bank of Armenia 2006, Analytical Study Based on the Survey on Money Transfers Received From Abroad by the Households in Armenia in 2005, Central Bank of Armenia, Yerevan, 2006.

Central Bank of Russia 2007, Cross-border transactions of individuals (residents and nonresidents) in breakdown by countries in 2007, Cross-border Transactions of Individuals (Residents and Nonresidents) in Breakdown by Countries, viewed

$<$ http://www.cbr.ru/eng/statistics/print.aspx?file=CrossBorder/C-

b_trans_countries_07_e.htm\&pid=svs\&sid=TGO_sp>,

Central Bank of Russia 2008a, Cross-border transactions of individuals (residents and nonresidents) in breakdown by countries in 2008, Cross-border Transactions of Individuals (Residents and Nonresidents) in Breakdown by Countries, viewed 
<http://www.cbr.ru/eng/statistics/print.aspx?file=CrossBorder/C-

b_trans_countries_08_e.htm\&pid=svs\&sid=TGO_sp>.

Central Bank of Russia 2008b, Cross-border remittances via money transfer operators and post offices in breakdown by countries 2008, Cross-border Remittances via Money Transfer Operators and Post Offices in Breakdown by Countries, $\begin{array}{llll}\text { viewed } & \text { accessed } & \text { 2013, }\end{array}$ $<$ http://www.cbr.ru/eng/statistics/CrossBorder/Crossborder_08_e.pdf?pid=svs\&sid=TGO_obz>,.

Central Bank of Russia 2009, Cross-border transactions of individuals (residents and nonresidents) in breakdown by countries in 2009, Cross-border Transactions of Individuals (Residents and Nonresidents) in Breakdown by Countries, viewed $13 \quad$ September 2013, <http://www.cbr.ru/eng/statistics/print.aspx?file=CrossBorder/Cb_trans_countries_09_e.htm\&pid=svs\&sid=TGO_sp>.

Central Bank of Russia 2010, Cross-border transactions of individuals (residents and nonresidents) in breakdown by countries in 2010, Cross-border Transactions of Individuals (Residents and Nonresidents) in Breakdown by Countries, $\begin{array}{llll}\text { viewed } & 13 & \text { September }\end{array}$ $<$ http://www.cbr.ru/eng/statistics/print.aspx?file=CrossBorder/Cb_trans_countries_10_e.htm\&pid=svs\&sid=TGO_sp>.

Central Bank of Russia 2011, Cross-border transactions of individuals (residents and nonresidents) in breakdown by countries in 2011, Cross-border Transactions of Individuals (Residents and Nonresidents) in Breakdown by Countries, viewed 
<http://www.cbr.ru/eng/statistics/print.aspx?file=CrossBorder/C-

b_trans_countries_11_e.htm\&pid=svs\&sid=TGO_sp>.

Central Bank of Russia 2012, Cross-border transactions of individuals (residents and nonresidents) in breakdown by countries in 2012, Cross-border Transactions of Individuals (Residents and Nonresidents) in Breakdown by Countries, viewed $13 \quad$ September 2013, <http://www.cbr.ru/eng/statistics/print.aspx?file=CrossBorder/Cb_trans_countries_12_e.htm\&pid=svs\&sid=TGO_sp>,.

de Luna-Martinez, J 2005, 'Workers' remittances to developing countries: A survey with central banks on selected public policy issues", World Bank Policy Research Working Paper 3638, World Bank Publications, Washington, DC, 2005.

European Bank for Reconstruction and Development 2012, "Transition Report 2012", Transition Report, EBRD, London, 2012.

Fetiniuc, A 2013, "Labor migration and remittances in the Republic of Moldova: are the remittances efficiently used by the migrants' households?" Diss. Dublin Business School.

Ghencea, B, Gudumac, I 2004, "Labour Migration and Remittances in the Republic of Moldova", Moldova Microfinance Alliance and Soros Foundation in Moldova.

Gusman, N 2007, "Denezhnie perevody kak otrazhenie processov migratsii", Economicheskoe Obozrenie EvrAzES, 4 (3), 17-20.

Ibragimova, S, Burzhubaev, T \& Temirov, A 2008, 'Country report on international migrants' remittances and poverty in the Kyrgyz Republic', A Study on 
International Migrants' Remittances in Central Asia and Southern Caucasus, Asian Development Bank, Manila, 2008.

International Monetary Fund 2009, Balance of Payments and International Investment Position Manual, Sixth Edition (BPM6). International Monetary Fund Washington, DC.

Kapur, D 2004, "Remittances-the new development mantra", G-24 Discussion Paper Series, № 29. United Nations, New York/Geneva.

Kupets, O 2012. "The development and the side effects of remittances in the CIS countries: The case of Ukraine", Research Report CARIM-East RR2012/02 (European University Institute Badia Fiesolana).

Lerch, M, Wanner, P \& Haug, W 2008, "The measurement of remittances in industrialized countries-or how to limit multiple biases", Background Paper for the Joint UNECE/World Bank/US Census Bureau Expert Group Meeting on the Contribution of Household Surveys to Measuring Remittances. Suitland, United States.

Luecke, M, Mahmoud, TO \& Steinmayr, A 2009, "Labour migration and remittances in Moldova: Is the boom over", International Organization for Migration, Moldova Office, Chisinau, 2009.

Lueth, E \& Ruiz-Arranz, M 2006, „A gravity model of workers' remittances”, IMF Working Paper WP/06/290, International Monetary Fund, Washington, DC, 2006.

Makhmutova, M, Makatova, A, Kourmanova, A, Abdullaev, U, Dienova, M \& Bakas Uuly, B 2008, "Country report on remittances of international migrants and the 
financial sector in Kazakhstan", Study on International Migrants Remittances in Central Asia and South Caucasus, Asian Development Bank, Manila, 2008.

Melkadze, G 2012, "Macroeconomic determinants of remittances in Georgia: A dynamic panel data approach". International School of Economics at Tbilisi State University, Tbilisi.

Mogilevsky, R \& Atamanov, A 2008, "Country report on remittances of international migrants and the financial sector in the Kyrgyz Republic", A Study on International Migrants' Remittances in Central Asia and South Caucasus, Asian Development Bank, Manila, 2008.

Mughal, AG 2007, "Migration, remittances, and living standards in Tajikistan". International Organization for Migration, Dushanbe, 2007.

National Bank of Ukraine 2013, "Remittances in Ukraine", viewed 19 May 2013 $<$ http://www.bank.gov.ua/doccatalog/document?id=80651>.

Poghossian, A, Hakobyan, I \& Saidov, F 2010, "Migrant remittances to Tajikistan: The potential for savings, economic investment and existing financial products to attract remittances". ILO Subregional Office for Eastern Europe and Central Asia, Moscow.

Ratha, D \& Shaw, W 2007, "South-South migration and remittances", Working Paper № 102, World Bank Washington, DC.

Rossiyskoe Informatsionnoe Agentstvo - Novosti 2012. "Ezhegodno v Rossiyu vezzhayut 14 millionov migrantov", Demoscope Weekly, 531-532, viewed 17 May 2013, http://demoscope.ru/weekly/2012/0531/rossia01.php. 
RusSlavBank 2009, "Denezhnie perevody kak metod otsenki migratsionnih protsessov", Press-release, viewed 15 May 2013, http://www.russlavbank.com/prcenter/newsdetail/642.html.

Rustamov, V 2008, "Country report on remittances of international migrants and poverty in Azerbaijan", A Study on International Migrants' Remittances in Central Asia and South Caucasus. Asian Development Bank, Manila.

Shelburne, R \& Palacin, J 2007, "Remittances in the CIS: Their economic implications and a new estimation procedure", Discussion Paper Series № 2007.5. United Nations Economic Commission for Europe, Geneva, 2007.

Shonkwiler, JS, Grigorian, D \& Melkonyan, T 2011, "Controlling for the underreporting of remittances", Applied Economics, 43 (30), 4817-26.

State Committee for the Republic of Uzbekistan on Demonopolization, Support of Competition and Entrepreneurship 2006, "International money transfer services market in Uzbekistan. Development Competition, and Trends", in Antimonopoly Policy Improvement Center (ed.). Tashkent, 2006.

Todoroki, E, Celik, K \& Kholmatov, M 2011, "Alternative remittance systems in Kazakhstan", World Bank, Washington, DC.

Tumasyan, M, Manukyan, Y, Torosyan, G, Terzikyan, G \& Mnatsakanyan, V 2008, "Country report on remittances of international migrants and poverty in Armenia", A Study on International Migrants' Remittances in Central Asia and South Caucasus, Asian Development Bank, Manila, 2008.

Tyuryukanova, E 2005, "Forced labour in the Russian Federation today: Irregular migration and mrafficking in human beings", International Labour Organization, Geneva 2006. 
Zipf, GK 1946, "The P 1 P 2/D hypothesis: on the intercity movement of persons", American Sociological Review, 11 (6), 677-86.

Zykova, T 2008, "Rubl v perevode”, Rossiyskaya Gazeta, 22 March 2008, 1. 